\title{
Groundwater fluoride in Sri Lanka: opportunities to mitigate the risk at maximum contaminant level
}

\author{
Nirosha Ranasinghe $^{1 *}$, Estie Kruger ${ }^{1}$, Rohana Chandrajith ${ }^{2}$, Marc Tennant ${ }^{1}$ \\ (Index words: groundwater, skeletal fluorosis, risk assessment, geographic informations systems (GIS)
}

\begin{abstract}
Introduction High groundwater fluoride $(F)$ is one of the major environmental hazards in the dry zone of Sri Lanka. The prolonged exposure to $\mathrm{F}$ at maximum contaminant levels can give rise to lifelong debility and disability among its inhabitants.

Objective This study investigated the $\mathrm{F}$ contamination in groundwater resources in Sri Lanka above recommended Maximum Contaminant Levels (MCL) and possibilities to mitigate the health risk.
\end{abstract}

Methods Groundwater samples (6107) were randomly collected from different geographic areas of the country, and categorised as hazardous, if it exceeded the maximum contaminant level of $4 \mathrm{mg} / \mathrm{L}$ (the level at which bone health is compromised). The minimum distances from a hazardous to a relatively safe $F$ groundwater source (below $1.0 \mathrm{mg} / \mathrm{L}$ and $1.5 \mathrm{mg} / \mathrm{L}$ ) were determined using geospatial analysis.

Results Only 2.3\% (142) of the total sample was found to be hazardous to skeletal health. Optimal F sources were identified in close proximity to highly contaminated sources $(>4.0 \mathrm{mg} / \mathrm{L})$, some even within a walking distance of 500 metres.

Conclusion The identification and elimination of maximally contaminated sources, possibly by dilution with widely available low $\mathrm{F}$ sources in close proximity, would be a more feasible and cost effective approach to ensure long term public health benefits.

Ceylon Medical Journal 2018; 63: 174-179

DOI: http://doi.org/10.4038/cmj.v63i4.8768

\section{Introduction}

Groundwater fluoride $(\mathrm{F})$ is frequently found in certain geochemical environments. Long-term consumption of high F content groundwater can lead to adverse health effects. It is known globally as one of the most important toxicological environmental hazards [1]. The long-term exposure to high levels of $\mathrm{F}$, that exceed the maximum contaminant levels (MCL), can cause lifelong debility and disability. Skeletal fluorosis, a serious bone disorder resembling osteoporosis, is caused by the chronic exposure to $\mathrm{F}$ that exceeds MCL. It is characterised by extreme density and hardness and abnormal fragility of the bones. The adverse skeletal effects cause pain and tenderness in bones and increase the likelihood of bone fractures [2]. The skeletal and crippling fluorosis occurs mostly in adults exposed to excessive levels of $\mathrm{F}$ in drinking water over the course of a lifetime, and it may even cause neurological complications [3]. It was also reported in children, presenting as juvenile skeletal fluorosis, where prolonged exposure to higher concentration of $\mathrm{F}$ was evident [4].

The natural occurrence of $\mathrm{F}$ in groundwater is mainly due to circulation of water in rocks and soils [5]. The geochemistry of the F-ion (ionic radius $136 \mathrm{pm}$ ) is similar to that of the $\mathrm{OH}$ - ion (ionic radius $140 \mathrm{pm}$ ), hence these two can be easily exchanged in the natural environment [6]. Fluoride has its mitigating effect against dental caries when ingested in small quantities $(<0.5 \mathrm{mg} / \mathrm{L})$, whereas in high concentrations, long-term exposure causes dental $(>1.5 \mathrm{mg} / \mathrm{L})$ and skeletal (>4.0 mg/L) fiuorosis [7]. The United States Environmental Protection Agency (EPA) announced a Maximum Contaminant Level Goal (MCLG) of $\mathrm{F}$ in drinking water sources for protection against the increased health risks over a lifetime [8,9]. The enforceable drinking water standard, the MCL, is currently set at the same level of MCLG, which is $4.0 \mathrm{mg} / \mathrm{L}$. It was enforced to prevent skeletal damage resulting from lifelong high $\mathrm{F}$ exposure. It is the maximum amount allowed in public water supplies, and consumers should be notified if the level is exceeded [9]. The EPA has further recommended a reference dose (RfD) of $0.08 \mathrm{mg} / \mathrm{kg} / \mathrm{day}$, an estimate of the daily exposure highly unlikely of skeletal damage during a lifetime $[8,9]$.

According to the WHO International Programme on Chemical Safety, skeletal fluorosis may be observed when

${ }^{1}$ International Research Collaborative - Oral Health and Equity, School of Human Sciences, The University of Western Australia, ${ }^{2}$ Department of Geology, Faculty of Science, University of Peradeniya, Sri Lanka.

Correspondence: NR e-mail: <nirosandi1976@gmail.com>. Received 26 September 2018 and revised version accepted 03 October 2018.

This is an open-access article distributed under the terms of the Creative Commons Attribution License, which permits unrestricted use, distribution, and reproduction in any medium, provided the original author and source are credited. 
drinking-water contains 3-6 mg/L of F, while crippling skeletal fluorosis appears with long term exposure to over $10 \mathrm{mg} / \mathrm{L}$ of $\mathrm{F}$ in drinking water [10]. The World Health Organisation (WHO) Guideline for Drinking Water Quality, states that there is an excess risk of adverse skeletal effects for a total intake of $14 \mathrm{mg}$ F/day, and suggestive evidence of an increased risk of effects on the skeleton with total intakes that exceed about $6 \mathrm{mg} /$ day [7]. Studies have shown that when the ingestion of $F$ exceeds $4 \mathrm{mg} /$ day, $50 \%$ is retained in the skeletal tissues while the rest is excreted through urine, and thereby skeletal $\mathrm{F}$ increases almost proportionately to the amount ingested and the duration of exposure [3].

The effects of fluoride exposure on the musculoskeletal system was discussed in several epidemiological studies when establishing the $4.0 \mathrm{mg} / \mathrm{L}$ as the MCL. There is clear evidence from India and China that skeletal fluorosis and an increased risk of bone fractures occur as a result of long-term excessive exposure to fluoride [11]. In Sri Lanka, F levels that exceed MCL in drinking water were reported in several previous studies carried out in the dry zone regions. Among 407 wells examined for $\mathrm{F}$ in the Thambuttegama area, $1.6 \%$ of wells had F levels ranging from 4 to $10 \mathrm{mg} / \mathrm{L}$ [12]. In Sri Lanka, skeletal effects due to groundwater $F$ has also been reported in a few studies $[12,13]$. However, the reported range of Community Fluorosis Index (CFI) values for seven high fluoride regions of Sri Lanka (1.33 to 1.84) only indicated the dominance of dental fluorosis as a public health problem, but not skeletal fluorosis. The CFI value exceeding 0.6 indicates dental fluorosis as public health problem, whereas 3.5 is the suggested CFI value for skeletal fluorosis [14]. A detailed study of bone disease of the rural populations in the dry zone of Sri Lanka is a high priority to estimate the actual burden [3]. The present study aimed to determine the groundwater F levels in Sri Lanka that exceed the US recommended MCL ( $>4 \mathrm{mg} / \mathrm{L})$, and study the proximity to the low $\mathrm{F}$ resources through distance-based Geographic Information System (GIS) measurements. Such knowledge is important in developing appropriate strategies to provide safe drinking water to rural communities in Sri Lanka.

\section{Methods}

The groundwater F in Sri Lanka were investigated using a cross-sectional descriptive study design. Permission was granted from the Department of Geology, University of Peradeniya, in Sri Lanka to access their groundwater F database. Ethical clearance was not considered as necessary as the data used was open access.

Sources: The study was based on previously published F measurements of randomly collected groundwater samples from 6107 shallow and deep wells in 21 districts in Sri Lanka during 2005-2015. The analysis for F was completed using the SPANDS method in most cases and the ion selective electrode method in some instances [12]. Geo- coordinates were already attached to the physical locations of each well.

\section{Geo-coding approach}

The well location data and linked F levels were transferred into QGIS (version 2.14.1) for geospatial analysis of $\mathrm{F}$ levels of groundwater samples. All data was transformed into Coordinate Reference System WGS84 for analysis.

\section{Levels of fluoride}

The groundwater $\mathrm{F}$ levels were categorised into three level bands as less than $0.5 \mathrm{mg} / \mathrm{L}$; less than $1.5 \mathrm{mg} / \mathrm{L}$ and greater than $4 \mathrm{mg} / \mathrm{L}$. All the groundwater sources that exceeded the F content of $4.0 \mathrm{mg} / \mathrm{L}$ were considered as 'maximally contaminated'. The minimum distance from a 'maximally contaminated' groundwater source to the nearest low $\mathrm{F}$ groundwater source (less than $1.5 \mathrm{mg} / \mathrm{L}$ and less than $1.0 \mathrm{mg} / \mathrm{L}$ ) were measured separately in geospatial analysis and used in further descriptive analysis.

\section{Results}

The total water well sample $(n=6107)$ largely represented the shallow and deep wells of the dry zone of Sri Lanka (Table 1). The results indicated $63 \%(n=3847)$ and $80.5 \%(n=4916)$ of water samples had a F level less than $1.0 \mathrm{mg} / \mathrm{L}$ and less than $1.5 \mathrm{mg} / \mathrm{L}$, respectively. The total number of water samples that exceed the MCL and the value predicted the risk of skeletal fluorosis were 142 $(2.3 \%)$.

Table 1. Distribution of water well locations by provinces and districts

\begin{tabular}{|c|c|c|c|}
\hline \multirow[t]{2}{*}{ Province } & \multirow[t]{2}{*}{ District } & \multicolumn{2}{|c|}{$\begin{array}{c}\text { Water well samples } \\
\text { collected }\end{array}$} \\
\hline & & No. & $\%$ \\
\hline \multirow[t]{3}{*}{ Central } & Kandy & 17 & 0.3 \\
\hline & Matale & 666 & 10.9 \\
\hline & Nuwara-Eliya & 4 & 0.1 \\
\hline \multirow[t]{3}{*}{ Eastern } & Ampara & 164 & 2.7 \\
\hline & Batticoloa & 4 & 0.1 \\
\hline & Trincomalee & 21 & 0.3 \\
\hline \multirow[t]{2}{*}{ North Central } & Anuradhapura & 1487 & 24.4 \\
\hline & Polonnaruwa & 744 & 12.2 \\
\hline \multirow[t]{2}{*}{ North Western } & Kurunegala & 541 & 8.9 \\
\hline & Puttalam & 789 & 12.9 \\
\hline Northern & Vavuniya & 69 & 1.1 \\
\hline \multirow[t]{2}{*}{ Sabaragamuwa } & Kegalle & 16 & 0.3 \\
\hline & Ratnapura & 138 & 2.3 \\
\hline \multirow[t]{3}{*}{ Southern } & Galle & 4 & 0.1 \\
\hline & Hambantota & 754 & 12.4 \\
\hline & Matara & 1 & 0.0 \\
\hline \multirow[t]{2}{*}{ Uva } & Badulla & 120 & 2.0 \\
\hline & Moneragala & 390 & 6.4 \\
\hline \multirow[t]{3}{*}{ Western } & Colombo & 5 & 0.1 \\
\hline & Gampaha & 93 & 1.5 \\
\hline & Kalutara & 74 & 1.2 \\
\hline
\end{tabular}


According to the distance specific GIS analysis, it was noteworthy to identify multiple low F sources among the highly contaminated sources $(>4.0 \mathrm{mg} / \mathrm{L})$, even within a distance of less than $500 \mathrm{~m}$ (Table 2 and Figure 1). The minimum distance observed between a high $\mathrm{F}$ well $(>4.0$ $\mathrm{mg} / \mathrm{L})$ and a low $\mathrm{F}$ well $(<1.0 \mathrm{mg} / \mathrm{L})$ was $42 \mathrm{~m}$ and the maximum distance was $7303 \mathrm{~m}$. Similarly, the minimum distance observed between a high $\mathrm{F}$ well $(>4.0 \mathrm{mg} / \mathrm{L})$ and a low $F$ well $(<1.5 \mathrm{mg} / \mathrm{L})$ was $42 \mathrm{~m}$ and the maximum distance was $4939 \mathrm{~m}$.

Results indicated that $25.4 \%$ of hazardous groundwater sources (> $4.0 \mathrm{mg} / \mathrm{L}$ wells) had a low F source
$(<1.0 \mathrm{mg} / \mathrm{L})$ available within a distance of $500 \mathrm{~m}$ (Table 2 and Figure 1). If the cut-off increased to the WHO guideline value for optimal $\mathrm{F}$ levels $(1.5 \mathrm{mg} / \mathrm{L})$, it was shown that $35.2 \%$ of high $\mathrm{F}$ wells $(>4.0 \mathrm{mg} / \mathrm{L}$ wells) had a low $\mathrm{F}$ well $(<1.5 \mathrm{mg} / \mathrm{L})$ within a distance of $500 \mathrm{~m}$ (Table 2 and Figure 2). Correspondingly, if a distance of $1 \mathrm{~km}$ was considered, $50 \%$ of maximally contaminated groundwater sources ( $>4.0 \mathrm{mg} / \mathrm{L}$ wells) had a low $\mathrm{F}$ source $(<1.0 \mathrm{mg} / \mathrm{L})$ available (Table 2 and Figure 1) within $1 \mathrm{~km}$. Based on the WHO permissible level of $1.5 \mathrm{mg} / \mathrm{L}, 69 \%$ of high F wells (>4.0 $\mathrm{mg} / \mathrm{L}$ wells) had a low $\mathrm{F}$ well of $<1.5 \mathrm{mg} / \mathrm{L}$ available (Table 2 and Figure 2) within $1 \mathrm{~km}$.

Table 2. Number and percentage of high $F$ wells $(>4 \mathrm{mg} / \mathrm{L}$ ) having a low $F$ ground water sources $(<1 \mathrm{mg} / \mathrm{L}$ and $<1.5 \mathrm{mg} / \mathrm{L}$ ) at nearest distance

\begin{tabular}{|c|c|c|c|c|}
\hline \multirow{3}{*}{ Physical Accessibility } & \multicolumn{4}{|c|}{ Number and $\%$ of $>4 \mathrm{mg} / \mathrm{L}$ wells } \\
\hline & \multicolumn{2}{|c|}{ Having nearest $<1.0 \mathrm{mg} / \mathrm{L}$} & \multicolumn{2}{|c|}{ Having nearest $<1.5 \mathrm{mg} / \mathrm{L}$} \\
\hline & No. $(\%)$ & $\begin{array}{c}\text { Cumulative } \\
\text { No. (\%) }\end{array}$ & No. $(\%)$ & $\begin{array}{c}\text { Cumulative } \\
\text { No. (\%) }\end{array}$ \\
\hline $\begin{array}{l}\text { Easy } \\
(0-150 \mathrm{~m})\end{array}$ & $4(2.8 \%)$ & $4(2.8 \%)$ & $5(3.5 \%)$ & $5(3.5 \%)$ \\
\hline $\begin{array}{l}\text { Moderate } \\
(150-500 \mathrm{~m})\end{array}$ & $32(22.5 \%)$ & $36(25.4 \%)$ & $45(31.6 \%)$ & $50(35.2 \%)$ \\
\hline $\begin{array}{l}\text { Hard } \\
(501-1000 \mathrm{~m})\end{array}$ & $35(24.6 \%)$ & $71(50 \%)$ & $48(33.8 \%)$ & $98(69 \%)$ \\
\hline $\begin{array}{l}\text { Very Hard } \\
(+1001 \mathrm{~m})\end{array}$ & $71(50 \%)$ & $142(100 \%)$ & $44(30.9 \%)$ & $142(100 \%)$ \\
\hline
\end{tabular}

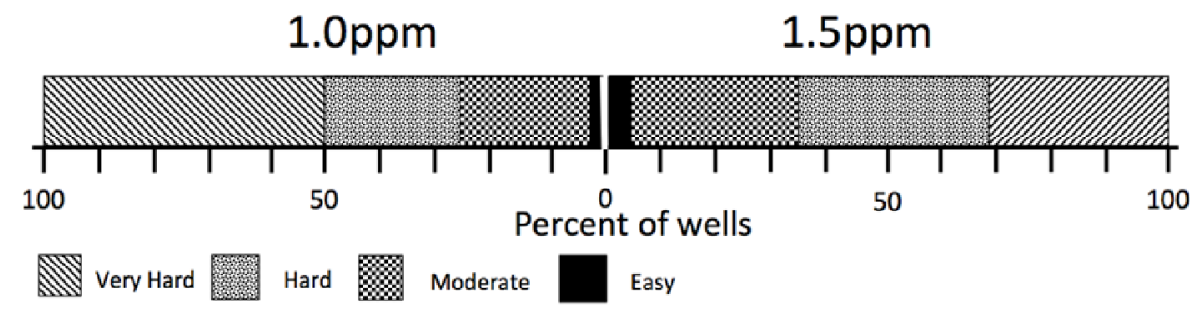

Figure 1. The cumulative percentage of $4 \mathrm{mg} / \mathrm{L}+$ wells at distance (metres) from each nearest $<1 \mathrm{mg} / \mathrm{L}$ well (left) and $<1.5 \mathrm{mg} / \mathrm{L}$ well (right). (ie: At $<500$ metres = easy \& moderately accessed, $35 \%$ of 4 $\mathrm{mg} / \mathrm{L}+$ wells have a well of $<1.5 \mathrm{mg} / \mathrm{L}$ available). 


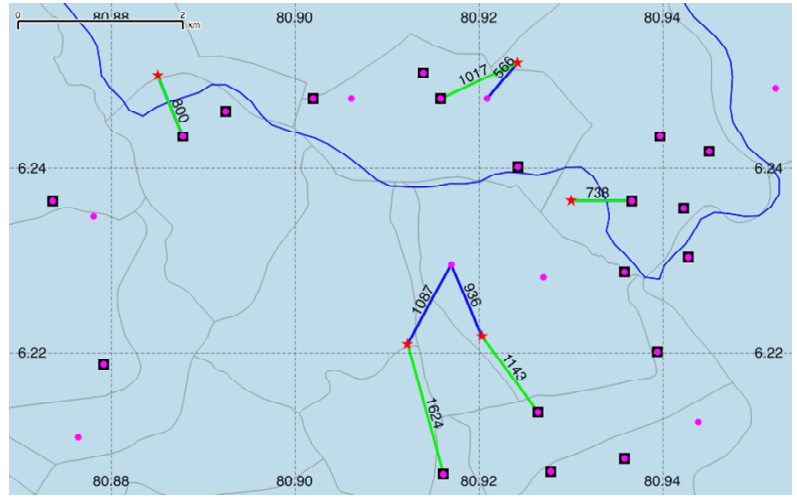

Figure 2. The heterogeneous nature of water well location and $F$ levels in Sri Lanka. A typical area of the map showing wells of 4 $\mathrm{mg} / \mathrm{L}+$ (red stars) and the distance in metres (green and blue lines and text) to the nearest well with water $F$ of less than $1 \mathrm{mg} / \mathrm{L}$ (pink spots) and $1.5 \mathrm{mg} / \mathrm{L}$ (black squares).
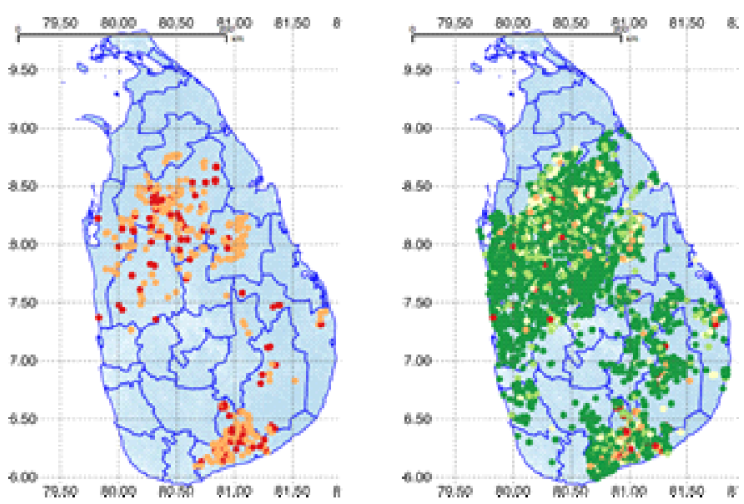

Figure 3. Well locations of different $F$ levels: 1 st map showing $>4.0 \mathrm{mg} / \mathrm{L}$ wells in dark red spots and $2.0-4.0 \mathrm{mg} / \mathrm{L}$ wells in light red spots; 2nd map showing $<2 \mathrm{mg} / \mathrm{L}$ wells in white, light green and dark green spots.

\section{Discussion}

A major part of the dry zone of Sri Lanka is affected by high $\mathrm{F}$ levels in groundwater. The vast majority of Sri Lankan rural communities in the dry zone mostly rely on groundwater for their domestic use and piped-born water supplies is mostly a privilege of only those who are living in urban cities. The rural population in Sri Lanka is as high as $77.4 \%$ of the country's total population [15]. Even though the WHO recommends a guideline value for drinking water quality as $1.5 \mathrm{mg} / \mathrm{L}$, it still remains a challenge to many arid regions where drinking water is a scarce commodity [16]. The scarce resource of water in the dry zone is not only used as a source of drinking water, but also for various agricultural, industrial, and recreational uses.
The present GIS analysis reported a high variability of the water F levels of the country in 6 specific categories. This scenario has been supported by a previous study that incorporated 8312 well water samples chemically analysed by the Water Supply and Drainage Board in Sri Lanka. Accordingly, the well water samples in Anuradhapura, Puttalama, Polonnaruwa, Rathnapura, Matale, Monaragala, Hambantota, Ampara and Kurunegala districts in Sri Lanka were found to have exceeded their MCL, with levels up to $13.7 \mathrm{mg} / \mathrm{L}, 13 \mathrm{mg} / \mathrm{L}$, $7.5 \mathrm{mg} / \mathrm{L}, 7.5 \mathrm{mg} / \mathrm{L}, 9 \mathrm{mg} / \mathrm{L}, 9 \mathrm{mg} / \mathrm{L}, 8.9 \mathrm{mg} / \mathrm{L}, 8.0 \mathrm{mg} / \mathrm{L}$ and $5.3 \mathrm{mg} / \mathrm{L}$, respectively. However, the mean F level found in all these districts were below the WHO water quality guideline $(1.5 \mathrm{mg} / \mathrm{L})$ and even below $1.0 \mathrm{mg} / \mathrm{L}$ in Puttalama, Matale, Ratnapura and Kurunegala districts [12]. A recent review conducted to study the periodically raised issues on water fluoridation concluded that it does not cause any adverse effects on bone strength, bone mineral density or fracture incidence at up to $1 \mathrm{mg} / \mathrm{L}$ upward adjustment [17]. In this study, the seasonal variation of groundwater $\mathrm{F}$ were not considered. However, some slight fluctuations of $F$ levels may occur due to excessive evaporation causing accumulation of salts in the surface soil layers in dry conditions [3]. A study done in dry zone region of Girandurukotte in the Uva Province showed only a negligible variation between pre- and post-monsoon sampling from same wells possibly due to more conservative nature of $\mathrm{F}$ in the natural geochemical system [18].

In response to the higher variability of $\mathrm{F}$ levels of water wells, the health burden can be minimized substantially by village level intervention, with wide community participation and empowerment. The adequacy of community awareness on the levels of $\mathrm{F}$ in their water supplies and perceived health risks has not received much attention in the $\mathrm{F}$ rich rural dry zone in Sri Lanka. The problem cannot be solved by recommending an optimal $\mathrm{F}$ level at country level, or at district level, whereas divisional health managers (e.g.: Medical Officer of Health) should be empowered to maintain and monitor the $\mathrm{F}$ well water database at divisional level to find reasonable solutions to the health risks in their area. In some F rich rural dry zone areas, F-safe drinking water is widely available, but there exists a lack of perception of its availability and associated health benefits.

Skeletal fluorosis was previously found to be associated with various factors, including the prevalence of high level of $\mathrm{F}$ intake, continual exposure to $\mathrm{F}$, strenuous manual labour, poor nutrition and impaired renal function due to disease [3]. Suggesting sustainable solutions to the groundwater $\mathrm{F}$ issue in regard to the associated factors has been discussed extensively in the last three decades. Various possible remedial and preventive measures have been adopted by the environmentalists and the healthcare professionals to mitigate the risk of high $\mathrm{F}$ in communities. The WHO has recommended the "provision of an alternative water source 
having a low or safe F limit' as the first line option [19, 20]. The methods available to access low F sources may be the surface water, rain water harvesting and the dilution of high $\mathrm{F}$ groundwater with easily accessible low $\mathrm{F}$ water. In Sri Lanka, rain water harvesting has been recognized as a successful intervention in a previous research study carried out in one locality, but it has not been implemented widely in all affected communities [21]. Surface water found to have safe F-levels is widely available in the dry zone of Sri Lanka. However, use of such resources have also been restricted and not recommended, as most of them are chemically and biologically contaminated and carry a greater health risk [12]. The link between the nutritional diet and the $\mathrm{F}$ absorption has also been considered, as calcium-rich foods were found to lower the bioavailability of $F[22,23]$. Hence, increasing the health awareness of associated factors and possible preventive measures should be given priority in mitigating the risk of fluorosis at both individual and population level. De-fluoridation is found to be the ultimate solution, if alternative sources of water is not available or feasible. As methods of defluoridation were found to be difficult and expensive, the WHO recommended the identification of safe drinking water supplies, as the preferred option for domestic use, particularly in less developed countries [19,20].

In the light of the discussion on high variability of the groundwater F levels in the dry zone of Sri Lanka, it is apparent that rural community empowerment for maximizing the use of widely available F-safe drinking water sources at the village level, also needs high priority. An efficient groundwater F monitoring system should be implemented at divisional health (Medical Officer of Health) level in Sri Lanka, as this can reduce the risk of adverse health effects considerably. Further action is required to introduce a regular groundwater monitoring system and public health notification system on health hazards as a part of proactive risk management strategy. Coordination between the health sector and the water supply and management sectors is essential to mitigate contamination events.

\section{Acknowledgements}

The corresponding author expresses her gratitude to the International Research Collaborative of Oral Health and Equity, The University of Western Australia and the Postgraduate Institute of Medicine, Sri Lanka in regard to the fellowship and the scholarship they offered her to engage in this extremely important $F$ research to address the contemporary public health issues. This research received no specific grant or funding from any funding agency in the public, commercial or non-profit sector.

\section{Competing interest}

None to declare.

\section{References}

1. Jha, SK, Singh RK, Damodaran T, Mishra VK. Fluoride in groundwater: Toxicological exposure and remedies. Journal of Toxicology and Environmental Health, Part B 2013; 16: 52-66.

2. Kurdi, MS. Chronic fluorosis: The disease and its anaesthetic implications. Indian J of Anaesthesia 2016; 60(3): $157-62$

3. Dissanayake CB. Water quality in the dry zone of Sri Lanka - Some interesting health aspects. J Natn Sci Foundation Sri Lanka 2005; 33(3):161-8.

4. Jarvis HG, Heslop P, Kisima J, Gray WK, Ndossi G, Maguire A, et al. Prevalence and aetiology of juvenile skeletal fluorosis in the south-west of the Hai district, Tanzania - A community-based prevalence and case-control study. Trop Med Int Health 2013; 18: 222-9.

5. Suneetha M, Syama Sundar B, Ravindhranath K. Groundwater pollution and adverse effects on health by fluoride ions. Journal of Chemical and Pharmaceutical Research 2015; 7(11): 292-305. ISSN: 0975-7384 CODEN(USA): JCPRC5.

6. Dissanayake CB, Chandrajith R. Medical geochemistry of tropical environments. Earth Science Reviews 1999; 47: 219-58. PII: S0012- 825299 00033-1

7. WHO (World Health Organization). Guidelines for drinking water quality, World Health Organization. Vol 1, Recommendations, 3rd edn. Geneva;2004.

8. United States Environmental Protection Agency (EPA). Questions and Answers on Fluoride. Office of Water (4606M); January 2011. (accessed on 15/06/208).

9. National Research Council 2006. Fluoride in Drinking Water. A Scientific Review of EPA's Standards. Washington, DC: The National Academies Press.

10. IPCS. Fluorine and Fluorides. Geneva, World Health Organization, International Programme on Chemical Safety (Environmental Health Criteria 36); 1984.

11. IPCS. Environmental Health Criteria 227 Fluorides. World Health Organisation, Geneva; 2002.

12. Chandrajith R, Padmasiri JP, Dissanayake CB, Prematilaka KM. Spatial distribution of fluoride in groundwater of Sri Lanka. Journal of Natn Sci Foundation Sri Lanka 2012; 40(4): 303-9.

13. Dissanayake JK, Abeygunasekara A, Jayasekara R, Ratnatunga C, Ratnatunga NV. Skeletal fluorosis with neurological complications. Ceylon Med J 1994; 39(1): 48-50.

14. Dissanayake CB. The fluoride problem in the groundwater of Sri Lanka environmental management and health. Int $J$ Environ Stud 1991; 38: 137-55.

15. Ministry of Policy Planning and Economic Affairs, Department of Census and Statistics, Census of Population and Housing 2012. Ministry of Policy Planning and Economic Affairs, Colombo, Sri Lanka; 2015.

16. Brunt R, Vasak L, Griffioen J. Fluoride in groundwater: 
Probability of occurrence of excessive concentration on global scale. International Groundwater Resources Assessment Centre. Report nr SP 2004-2. Utrecht: IGRAC.

17. Demos LL, Kazda H, Cicuttini FM, Sinclair MI, Fairley CK. Water Fluoridation, Osteoporosis, Fractures - recent developments. Australian Dental Journal 2001; 46(2): 80-7.

18. Wickramarathna S, Balasooriya S, Diyabalanage S, Chandrajith R. Tracing environmental aetiological factors of chronic kidney diseases in the dry zone of Sri Lanka - A hydrogeochemical and isotope approach. Journal of Trace Elements in Medicine and Biology 2017; 44: 298-306.

19. World Health Organization. Fluoride in drinking water. London, UK: World Health Organization, IWA Publishing; 2006.
20. World Health Organization 2018. Water related diseases. Available at: https://www.who.int/water_sanitation_ health/ diseases-risks/diseases/fluorosis/en/ (accessed on 26/12/ 2018).

21. Perera R, Johnson N, Usgodaarachchi U, Ariyananda T. Prevention of Dental Fluorosis by harvesting rain water in Sri Lanka. Research Report Fluoride 2013; 46(1): 29-33.

22. Susheela AK, Kumar A, Bhatnagar M, Bahadur R. Prevalence of endemic fluorosis with gastrointestinal manifestations in people living in some North-Indian villages. Fluoride 1993; 26: 97-104.

23. Dinesh C. Fluoride and human health cause for concern. Indian J Environ Protect 1998; 19: 81-9. 